\title{
Ecofriendly production of silver nanoparticles using Candida utilis and its mechanistic action against pathogenic microorganisms
}

\author{
Shailesh R. Waghmare $\cdot$ Mustopa N. Mulla • \\ Suryakant R. Marathe $\cdot$ Kailas D. Sonawane
}

Received: 28 October 2013/ Accepted: 10 January 2014/Published online: 24 January 2014

(c) The Author(s) 2014. This article is published with open access at Springerlink.com

\begin{abstract}
Silver nanoparticles (AgNPs) have attracted great interest due to their applications in various areas. In the present study ecofriendly biosynthesis of extracellular silver nanoparticles was carried out using Candida utilis NCIM 3469. Characterization of synthesized AgNPs was done by UV-visible spectroscopy, Scanning electron microscopy and antibacterial activity. AgNPs are found spherical in shape with size in the range of $20-80 \mathrm{~nm}$. AgNPs showed antibacterial activity against pathogenic organisms such as Pseudomonas aeruginosa, Staphylococcus aureus, and Escherichia coli. The SEM analysis confirms the antibacterial activity of Ag nanoparticles due to damage of cytoplasmic membrane. AgNPs synthesized by $C$. utilis could be applicable in the development of antibacterial water filters for treatment of water.
\end{abstract}

Keywords Ecofriendly - Silver nanoparticles ·

Candida utilis - Antibacterial $\cdot$ Pseudomonas aeruginosa

\section{Introduction}

Silver nanoparticles have recently attracted a lot of interest due to their distinctive properties such as large surface areas, unique physical, chemical and biological properties (Sharma et al. 2009; Zhou et al. 2009). Silver nanoparticles

S. R. Waghmare $(\bowtie) \cdot$ M. N. Mulla · S. R. Marathe .

K. D. Sonawane

Department of Microbiology, Shivaji University,

Kolhapur 416004, Maharashtra, India

e-mail: shlshwaghmare@gmail.com

K. D. Sonawane

Department of Biochemistry, Shivaji University,

Kolhapur, Maharashtra, India are emerging as a new generation of antibacterial agent (Rai et al. 2009) medical applications (Atyeh et al. 2007; Chang and Weinstein 1975), and antibacterial water filter (Jain and Pradeep 2005). The outbreak of infectious diseases caused by different pathogenic bacteria as well as the development of antibiotic resistance (Hsueh 2010; Kumarasamy et al. 2010; Pitout 2010) has prompted pharmaceutical companies and researchers to search for new antibacterial agents. Among nanomaterials like copper, zinc, titanium, magnesium, silver, gold, and alginate, silver nanoparticles have proved to be the most effective as they have good antibacterial efficacy against bacteria, viruses and other eukaryotic microorganisms (Rai et al. 2009). Different studies have been performed to check the bactericidal effect of silver nanoparticles against Gram negative and Gram positive bacteria, but the bactericidal mechanism of this compound has not been clearly elucidated. Morones et al. (2005) studied the antibacterial activity of silver nanoparticles against four types of Gram negative bacteria, Escherichia coli, V. cholera, Pseudomonas aeruginosa and S. typhus. They have observed that these silver nanoparticles are attached to the surface of the cell membrane and disturb the function of cell membrane, penetrate bacteria, and release silver ions.

Water is the common breeding ground for many pathogens. In countries such as India, $80 \%$ of the diseases are due to bacterial contamination in drinking water. The removal or inactivation of pathogenic microorganisms is the last step in the treatment of wastewater. During the past few decades, several investigations have been carried out concerning the use of metal ions $(\mathrm{Ag}, \mathrm{Cu}, \mathrm{Zn}, \mathrm{Hg}, \mathrm{Ti}, \mathrm{Ni}$, Co) as bactericides for water disinfection (Feng et al. 2000; Islam et al. 2003). The use of metal nanoparticles for water disinfection is relatively new (Stoimenov et al. 2002; Zhang et al. 2003). Because of their high reactivity due to 
the large surface to volume ratio (Ichinose 1992), nanoparticles are expected to play a crucial role in water purification (Stoimenov et al. 2002; Zhang et al. 2003) when water becomes an important commodity (Barraque, 2003). Pesticide removal from drinking water with the help of nanoparticles was reported by Nair and Pradeep (2004).

Although, various chemical and biochemical methods are being explored for the AgNPs production, but microbes are exceedingly effective in this process (Narayanan and Sakthivel 2010). Biosynthesis of silver nanoparticles from bacteria, fungi, yeast, plants, and fruits have been reported (Kowshik et al. 2003). Based on their enormous biotechnological applications, microorganisms such as bacteria, fungi, and yeast are now regarded as possible ecofriendly "nano-factories" (Ahmad et al. 2002). The detail mechanism of microbial synthesis of Ag nanoparticles is yet to be elucidated, but several reports suggested role of certain enzymes such as NADH-dependent reductase from Fusarium oxysporum (Ahmad et al. 2002), proteins from Phanerochaete chrysosporium (Vigneshwaran et al. 2006) and Plectonema boryanum (Lengke et al. 2007) in the synthesis of nanoparticles. Here, we first time report the biofabrication of silver nanoparticles using Candida utilis and its application as antimicrobial agent against pathogenic microorganisms.

\section{Materials and methods}

\section{Microorganisms}

The cultures of C. utilis NCIM 3469, E. coli NCIM 2832, Salmonella typhimurium NCIM 2501, Candida albicans NCIM 3466 and P. aeruginosa NCIM 5032 used in this study were obtained from National Collection of Industrial Microorganisms (NCIM), Pune, Maharashtra, India.

Biosynthesis of silver nanoparticles

The $C$. utilis was grown on MGYP medium containing malt extract 3.0, glucose 10.0, yeast extract 3.0, peptone 5.0 and agar 20.0 in $1,000 \mathrm{ml}$ distilled water. The fresh culture of $C$. utilis was inoculated in $100 \mathrm{ml}$ mineral medium containing $\mathrm{NaNO}_{3}: 3, \mathrm{~K}_{2} \mathrm{HPO}_{4}: 1, \mathrm{KCl}: 0.5$, $\mathrm{MgSO}_{4} \cdot 7 \mathrm{H}_{2} \mathrm{O}: 0.5, \mathrm{FeSO}_{4}: 0.01$, yeast extract 0.1 , peptone: 0.5 per $1,000 \mathrm{ml}$ distilled water and flask was incubated at $30{ }^{\circ} \mathrm{C}$ for $48 \mathrm{~h}$. After incubation the cells were separated by centrifugation at $5,000 \mathrm{rpm}$ for $15 \mathrm{~min}$ and $100 \mathrm{ml}$ supernatant was collected in $250 \mathrm{ml}$ Erlenmeyer flask containing $10 \mathrm{ml} \mathrm{AgNO}_{3}$ solution (contain $37.18 \mathrm{mg}$ $\mathrm{AgNO}_{3}$ ) which makes the final concentration of $\mathrm{AgNO}_{3}$ $2 \mathrm{mM}$. The flask was then incubated at $30{ }^{\circ} \mathrm{C}$ on shaking incubator at $120 \mathrm{rpm}$ in dark. After $6 \mathrm{~h}$, the sample was taken out for UV-visible (UV-Vis) spectrophotometric analysis. Another flask containing a mixture of $100 \mathrm{ml}$ supernatant and $10 \mathrm{ml} \mathrm{AgNO}_{3}$ solution (contain $37.18 \mathrm{mg}$ $\mathrm{AgNO}_{3}$ ) was autoclaved at $120{ }^{\circ} \mathrm{C}$ for $15 \mathrm{~min}$ and further analyzed by UV-Vis spectrophotometer.

In a separate experiment, culture of $C$. utilis was grown in $100 \mathrm{ml}$ mineral medium as described above for $24 \mathrm{~h}$. After incubation, cell biomass was collected and then added in $2 \mathrm{mM} 100 \mathrm{ml} \mathrm{AgNO}_{3}$ solution and incubated at shaking condition. The $\mathrm{AgNO}_{3}$ reduced to AgNPs shows change in color of $\mathrm{AgNO}_{3}$ from colorless to brown was monitored after $24 \mathrm{~h}$ for production of AgNPs by spectrophotometric analysis between the wavelength ranges 300 to $700 \mathrm{~nm}$. The effect of different concentrations of $\mathrm{AgNO}_{3}$ such as 2, 4, 6, 8, and $10 \mathrm{mM}$ on synthesis of AgNPs was monitored for $24 \mathrm{~h}$.

\section{Characterization of AgNPs}

The formation of AgNPs was monitored by UV-Vis spectroscopy by recording the spectra between 300 and $700 \mathrm{~nm}$ and simultaneously monitoring the appearance of the characteristic peak at $39-420 \mathrm{~nm}$ using Shimadzu U-1800 double beam spectrophotometer. The suspension obtained at the time point of maximum production of silver nanoparticles was air dried and then subjected to SEM, using JEOL JSM 6360 (Japan) Scanning Electron Microscope and micrographs were taken.

Antibacterial activity of AgNPs

AgNPs synthesized using whole cells of $C$. utilis, supernatant with heat treatment and $6 \mathrm{mM}$ aqueous solution of silver nitrate as control were tested for antibacterial activity against pathogenic microorganisms such as $S$. aureus, $P$. aeruginosa, and E. coli. The antibacterial activity was tested by the agar disc diffusion method (Kim et al. 2007) and zone of inhibition was noted.

To examine bactericidal effect on Gram negative organism, $P$. aeruginosa was used as model organism. The fresh culture of $P$. aeruginosa was inoculated in the nutrient broth and then incubated at $37{ }^{\circ} \mathrm{C}$ for $24 \mathrm{~h} .100 \mu \mathrm{l}$ of nanoparticle solution having concentration $1 \mathrm{mg} \mathrm{ml}^{-1}$ was added in the nutrient broth containing $P$. aeruginosa. After $2 \mathrm{~h}$ of incubation, the sample was prepared according to method described by Galabova et al. (1996) for SEM analysis.

Statistical analysis

Results obtained were the mean of three or more determinants. Analysis of variance was carried out on all data at $p<0.05$ using Graph Pad software (GraphPad InStat version 3.00, GraphPad Software, San Diego, CA, USA). 


\section{Results}

Biosynthesis of Ag nanoparticles

The aqueous $\mathrm{AgNO}_{3}$ was reduced to metallic silver. The synthesis of silver nanoparticles was monitored in three flasks: (1) in presence of supernatant at $30{ }^{\circ} \mathrm{C}$; (2) in presence of supernatant at temperature $120{ }^{\circ} \mathrm{C}$ for $15 \mathrm{~min}$; (3) in the presence of cell biomass of $C$. utilis. It has been observed that the silver nanoparticles were produced when $\mathrm{AgNO}_{3}$ mixed with supernatant and heated at $120{ }^{\circ} \mathrm{C}$ for $15 \mathrm{~min}$, whereas no brown color was seen in the flask which was kept at $30{ }^{\circ} \mathrm{C}$. These results indicate the role of temperature in the synthesis of silver nanoparticles. In the case of flask containing cell biomass of $C$. utilis with $\mathrm{AgNO}_{3}$, it was found that the intensity of brown color was increased as the incubation time increases at $30{ }^{\circ} \mathrm{C}$. It confirms the synthesis of silver nanoparticles by $C$. utilis, as shown in Fig. 1.

\section{Characterization of AgNPs}

After $24 \mathrm{~h}$ of incubation the aqueous silver nitrate turned colorless to brownish yellow in the presence of $C$. utilis cell biomass. UV-Vis spectra of solution revealed peak between 401 and $410 \mathrm{~nm}$, with maximum absorbance at $406 \mathrm{~nm}$. In the present study we have studied the effect of $\mathrm{AgNO}_{3}$ concentration on the synthesis of silver nanoparticles. As the concentration of $\mathrm{AgNO}_{3}$ increases from 2 to $6 \mathrm{mM}$, synthesis of AgNPs increases, whereas by increasing the concentration of $\mathrm{AgNO}_{3}$ up to $8 \mathrm{mM}$ the synthesis of AgNPs sharply decreases as depicted in Fig. 2. The UVVis spectra of aqueous silver nitrate solution when monitored separately did not show any peak between 40 and $410 \mathrm{~nm}$. SEM micrograph of synthesized silver nanoparticles revealed the formation of spherical nanoparticles

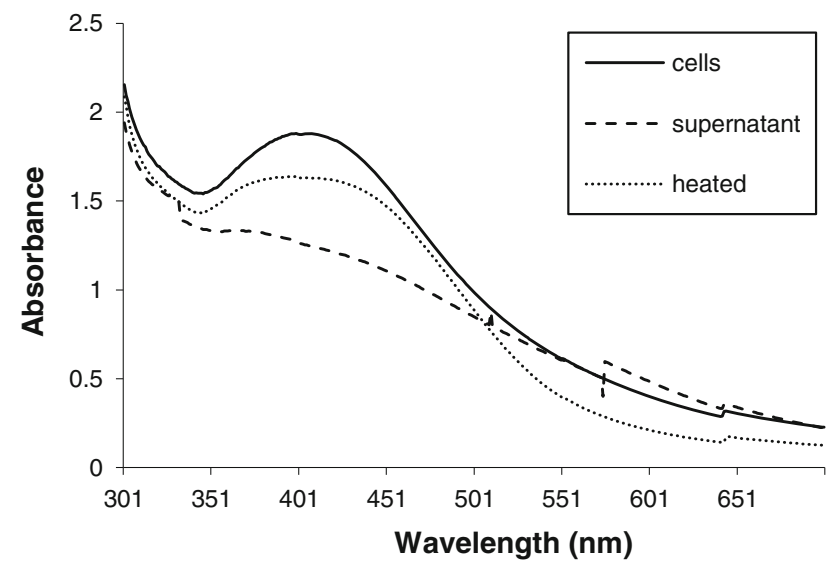

Fig. 1 UV-Vis spectroscopy of synthesized silver nanoparticles. Synthesis of silver nanoparticles was carried out using cells of $C$. utilis, supernatant and supernatant with heat treatment process with the size range of $20-100 \mathrm{~nm}$ along with some nanoclusters (Fig. 3).

Antibacterial activity of synthesized AgNPs

The antibacterial activity of synthesized AgNPs by cell biomass of $C$. utilis $(B)$, by the supernatant with heat treatment $(A)$ and control as aqueous solution of silver nitrate $(C)$ was tested on the Gram positive (S. aureus) and Gram negative ( $P$. aeruginosa, E. coli) organism. AgNPs showed more antibacterial activity against Gram negative organisms such as $P$. aeruginosa, and $E$. coli as compared to Gram positive organism, i.e., S. aureus (Fig. 4).

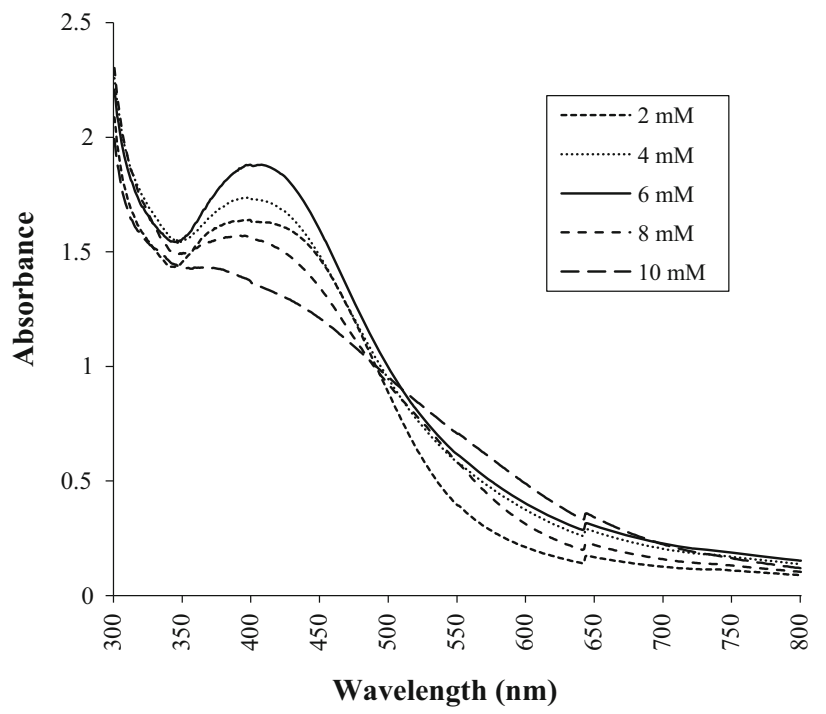

Fig. 2 Effect of silver nitrate concentration on synthesis of AgNPs. Synthesis of AgNPs was carried out at various concentration of silver nitrate such as $2,4,6,8$, and $10 \mathrm{mM}$ using cells of $C$. utilis

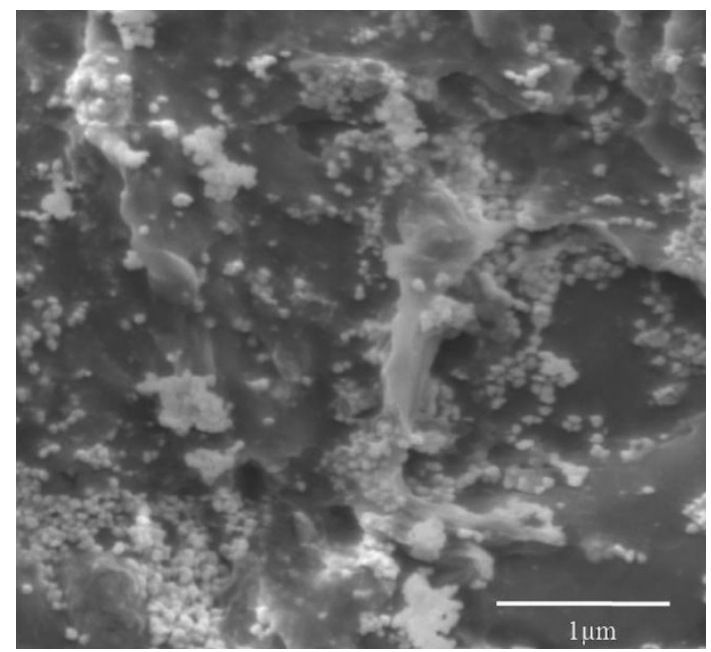

Fig. 3 Scanning Electron Microscopy of AgNPs. AgNPs synthesized by $C$. utilis analyzed for morphology by SEM 

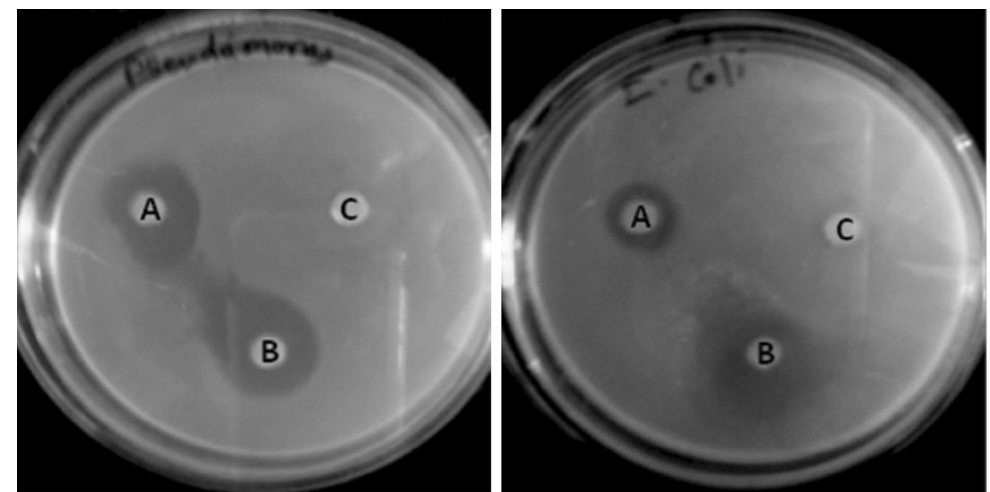

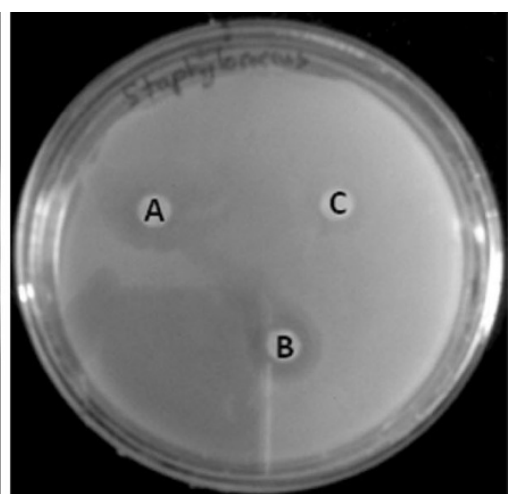

solution of silver nitrate (c) were tested against pathogens such as $P$. aeruginosa, E. coli, and $S$. aureus by disc diffusion method

utilis. The extracellular synthesis of silver nanoparticles had been reported earlier from other yeast such as salttolerant yeast MKY3 (Kowshik et al. 2003), C. guilliermondii (Mishra et al. 2011), Geotrichum sp. (Jebali et al. 2011). The extracellular synthesis of AgNPs would be of great advantage to industry, since it would minimize the steps involved in the purification of AgNPs. The color of the reaction solution turned from colorless to brown indicating the formation of silver nanoparticles similar to that observed in earlier study. This color arises due to the excitation of surface plasmon vibrations in the metal nanoparticles (Narayanan and Sakthivel 2010).

The silver nanoparticles were synthesized using cells of $C$. utilis, which are spherical nanoparticles with the size range of $20-80 \mathrm{~nm}$ along with some nanoclusters (Fig. 3), whereas salt-tolerant yeast MKY3 synthesizes hexagonal silver nanoparticles with the size range of 2-5 nm (Kowshik et al. 2003). Antibacterial activity of AgNPs synthesized by $C$. utilis was found to be inhibitory to both Gram positive as well as Gram negative groups of bacteria, but it has more potential against Gram negative organisms such as $P$. aeruginosa and E. coli than the Gram positive, i.e., S. aureus. The Ag nanoparticles have shown more antimicrobial activity

In this study, we have for the first time reported the extracellular synthesis of silver nanoparticles using $C$.

Fig. 5 SEM analysis of $P$. aeruginosa after the treatment with synthesized $\mathrm{Ag}$ nanoparticles (b) and native cells (a)
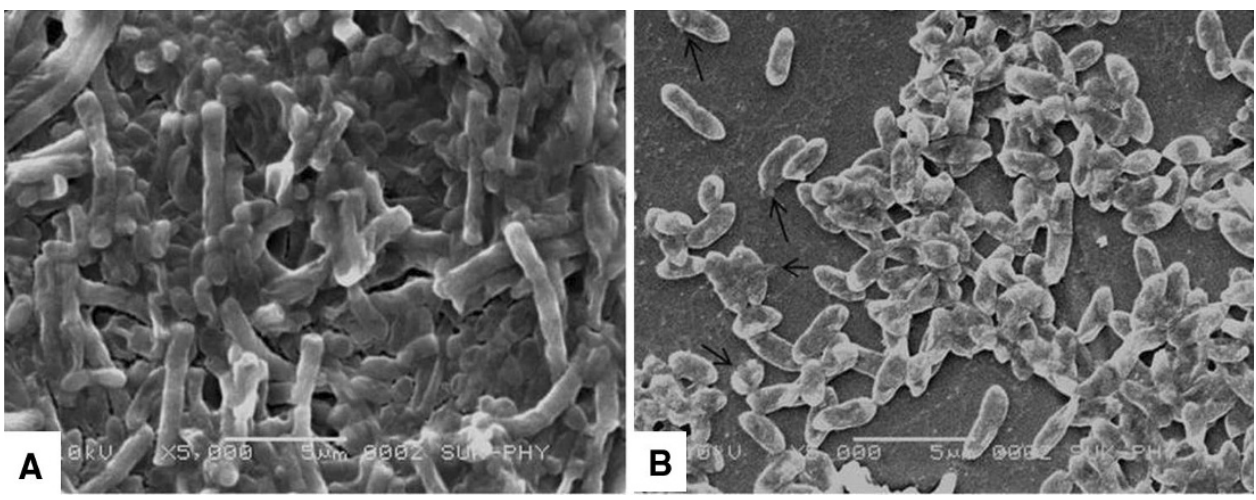
against Gram negative bacteria than the Gram positive bacteria. This could be because Gram negative bacterial cell wall contains thin layer of peptidoglycan whereas Gram positive bacterial cell wall contains thick layer (Le et al. 2010). The most of the disease causing Gram negative bacteria are transmitted through water, so the synthesized Ag nanoparticles impregnated with the polymer could be used for water purification filter systems (Jain and Pradeep, 2005).

The SEM micrograph of AgNPs treated with $P$. aeruginosa confirms the bactericidal activity of nanoparticles synthesized by $C$. utilis. The detailed mechanism of interaction and penetration of silver nanoparticles inside the cell has not been fully studied. The electrostatic attraction between negatively charged cell membranes and positively charged nanoparticles could be responsible for the interactions between nanoparticles and bacterial cells (Raffi et al (2008). The bactericidal activity of silver nanoparticles against pathogenic bacteria could be used in conjunction with advances in impregnation techniques and polymer technology to expand the range of applications of these nanoparticles in the preservation of food, disinfection of medical supplies and equipment, and decontamination of the surfaces of items such as toys and kitchenware (Matsumura et al. 2003). Besides their bactericidal activity and immediate antibacterial effect against a wide variety of pathogenic bacteria, silver nanoparticles have particular characteristics provided by the silver itself. It tends to induce low bacterial resistance and has low toxicity and minimal side effects after absorption by the body (Ip et al. 2006).

\section{Conclusion}

The present study concludes ecofriendly production of silver nanoparticles using yeast $C$. utilis NCIM 3469. It has more potential activity against Gram negative bacteria. Ag nanoparticles accumulate on the cell surface which causes cell membrane lysis as confirmed by SEM. The antibacterial activity of biofabricated AgNPs revealed applicability in the preparation of reactors for the treatment of waste water and in the development of antibacterial water filters for treatment of water.

Acknowledgments This work was supported by Department of Science and Technology, Government of India, New Delhi under the DST-PURSE scheme sanctioned to Department of Microbiology, Shivaji University, Kolhapur, Maharashtra, India.

Conflict of interest The authors declare that they have no conflict of interest.
Open Access This article is distributed under the terms of the Creative Commons Attribution License which permits any use, distribution, and reproduction in any medium, provided the original author(s) and the source are credited.

\section{References}

Ahmad A, Mukherjee P, Senapati S, Mandal D, Khan MI, Kumar R, Sastry M (2002) Extracellular biosynthesis of silver nanoparticles using the fungus Fusarium oxysporum. Colloids Surface B 28:313-318

Atyeh BS, Costagliola M, Hayek SN, Dibo SA (2007) Effect of silver on burn wound infection control and healing: review of the literature. Burns 33:139-148

Barraque B (2003) Past and future sustainability of water policies in Europe. Nat Resour Forum 27:200-211

Chang TW, Weinstein L (1975) Prevention of Herpes Keratoconjunctivitis in rabbits by silver sulfadiazine. Antimicrob Agents Ch 8:677-678

Feng QL, Wu J, Chen GQ, Cui FZ, Kim TN, Kim JO (2000) A mechanistic study of the antibacterial effect of silver ions on Escherichia coli and Staphylococcus aureus. J Biomed Mater Res-A 52:662-668

Galabova D, Tuleva B, Spasova D (1996) Permeabilization of Yarrowia lipolytica cells by Triton X-100. Enzyme Microb Tech 18:18-22

Hsueh PR (2010) New Delhi metallo-lactamase-1 (NDM-1): an emerging threat among Enterobacteriaceae. J Formos Med Assoc 109:685-687

Ichinose N (1992) Superfine particle technology. Springer, Berlin

Ip M, Lui SL, Poon VK, Lung I, Burd A (2006) Antimicrobial activities of silver dressings: an in vitro comparison. J Med Microbiol 55:59-63

Islam MS, Motahar HM, Banu AL, Sultana C, Quadir MA (2003) Antibacterial and antifungal activity of mixed ligand complexes of oxovanadium (IV), titanium (III) and cadmium (II) metal ions. Oriental J Chem 19:547-554

Jain P, Pradeep T (2005) Potential of silver nanoparticle-coated polyurethane foam as an antibacterial water filter. Biotechnol Bioeng 90:59-63

Jebali A, Ramezani F, Kazemi B (2011) Biosynthesis of Silver Nanoparticles by Geotrichum sp. J Clust Sci 22:225-232

Kim JS, Kuk E, Yu KN, Kim JH, Park SJ, Lee HJ, Kim SH, Park YK, Park YH, Hwang CY, Kim YK, Lee YS, Jeong DH, Cho MH (2007) Antimicrobial effects of silver nanoparticles. Nanomed 3:95-101

Kowshik M, Ashtaputre S, Kharrazi S, Vogel W, Urban J, Kulkarni SK, Paknikar KM (2003) Extracellular synthesis of silver nanoparticles by a silver-tolerant yeast strain MKY3. Nanomed 14:95-100

Kumarasamy KK, Toleman MA, Walsh TR, Bagaria J, Butt F, Balakrishnan R, Chaudhary U, Doumith M, Giske CG, Irfan S, Krishnan P, Kumar AV, Maharjan S, Mushtaq S, Noorie T, Paterson DL, Pearson A, Perry C, Pike R, Rao B, Ray U, Sarma JB, Sharma M, Sheridan E, Thirunarayan MA, Turton J, Upadhyay S, Warner M, Welfare W, Livermore DM, Woodford N (2010) Emergence of a new antibiotic resistance mechanism in India, Pakistan, and the UK: a molecular, biological, and epidemiological study. Lancet Inf Dis 10:597-602

Le AT, Tam LT, Tam PD, Huy PT, Huy TQ, Hieu NV, Kudrinskiy AA, Krutyakov YA (2010) Synthesis of oleic acid-stabilized 
silver nanoparticles and analysis of their antibacterial activity. Mat Sci Eng C 30:910-916

Lengke MF, Fleet ME, Southam G (2007) Biosynthesis of silver nanoparticles by filamentous cyanobacteria from a silver(I) nitrate complex. Langmuir 23:2694-2699

Matsumura Y, Yoshikata K, Kunisaki S, Tsuchido T (2003) Mode of bactericidal action of silver zeolite and its comparison with that of silver nitrate. Appl Environ Microb 69:4278-4281

Mishra A, Tripathy SK, Yun SI (2011) Bio-synthesis of gold and silver nanoparticles from Candida guilliermondii and their antimicrobial effect against pathogenic bacteria. J Nanosci Nanotechnol 11:243-250

Morones JR, Elechiguerra JL, Camacho A, Holt K, Kouri JB, Tapia J, Yacaman MJ (2005) The bactericidal effect of silver nanoparticles. Nanotechnology 16:2346-2353

Nair AS, Pradeep T (2004) Reactivity of Au and Ag nanoparticles with halocarbons. Appl Nanosci 59-63

Narayanan KB, Sakthivel N (2010) Biological synthesis of silver nanoparticles. Adv Colloid Interfac 156:1-13

Pitout JDD (2010) The latest threat in the war on antibacterial resistance. Lancet Inf Dis 10:578-579

Raffi M, Hussain F, Bhatti T, Akhter J, Hameed A, Hasan M (2008) Antibacterial Characterization of Silver Nanoparticles against E. Coli ATCC-15224. J Mater Sci Technol 24:192-196
Rai M, Yadav A, Gade A (2009) Silver nanoparticles as a new generation of antibacterials. Biotechnol Adv 27:76-83

Sharma VK, Yngard RA, Lin Y (2009) Silver nanoparticles: green synthesis and their antimicrobial activities. Adv Colloid Interf 145:83-96

Stoimenov PK, Klinger RL, Marchin GL, Klabunde KJ (2002) Metal oxide nanoparticles as bactericidal agents. Langmuir 18: 6679-6686

Vigneshwaran A, Kathe AA, Varadarajan PV, Nachne RP, Balasubramanya RH (2006) Biomimetics of silver nanoparticles by white rot fungus, Phaenerochaete chrysosporium. Colloids Surface B 53:55-59

Zhang LZ, Yu JC, Yip HY, Li Q, Kwong KW, Xu AW, Wong PK (2003) Ambient light reduction strategy to synthesize silver nanoparticles and silver-coated $\mathrm{TiO} 2$ with enhanced photocatalytic and bactericidal activities. Langmuir 19:10372-10380

Zhou M, Wei Z, Qiao H, Zhu L, Yang H, Xia T (2009) Particle size and pore structure characterization of silver nanoparticles prepared by confined arc plasma. J Nanomater 2009:1-5 